\title{
Maternal Cystatin C Serum is Higher in Women with Severe Preeclampsia
}

\section{Kadar Serum Cystatin C Lebih Tinggi pada Perempuan dengan Preeklampsia Berat}

\author{
Kurnia M Isasari', Wim T Pangemanan', Iskandar Zulqarnain', Kemas Rahadiyanto ${ }^{2}$ \\ ${ }^{1}$ Department of Obstetrics and Gynecology \\ ${ }^{2}$ Medical and Health Research Unit \\ Faculty of Medicine University of Sriwijaya/ \\ Dr. Mohammad Hoesin General Hospital \\ Palembang
}

\begin{abstract}
Objective: To determine the comparison between maternal cystatin $\mathrm{C}$ serum in severe preeclampsia and normal pregnancy.

Method: This was an observational study with cross sectional analytic approach. The subjects are sixty women with severe preeclampsia and normal pregnancy who met inclusion criteria. The maternal serum level of cystatin $C$ was automatically measured with Particle Enhanced Nephelometric Assay (PENIA).

Result: Mean serum level of cystatin $\mathrm{C}$ in severe preeclampsia was $1.169 \pm 0.311 \mathrm{mg} / \mathrm{l}$. Mean serum level of cystatin $C$ in normal pregnancy was $0.929 \pm 0.166$. There was a significant differences between maternal serum levels of cystatin C in women with severe preeclampsia compared with women with normal pregnancy.

Conclusion: There was a significant differences between maternal serum levels of cystatin $C$ in severe preeclampsia compared with normal pregnancy.

[Indones J Obstet Gynecol 2014; 2-1: 22-27]
\end{abstract}

Keywords: cystatin C, endotheliosis glomerulus, severe preeclampsia.

\begin{abstract}
Abstrak
Tujuan: Mengetahui perbandingan kadar serum cystatin C maternal pada preeklampsia berat dan hamil normal.

Metode: Studi observasional dengan rancangan cross sectional Enam puluh sampel penderita preeklampsia dan hamil normal yang memenuhi kriteria inklusi, yang berobat di RS Dr. Mohammad Hoesin Palembang dari Maret 2013 sampai April 2013. Kadar serum cystatin $C$ maternal diukur secara otomatisasi dengan metode particle-enhanced nephelometric assay (PENIA).
\end{abstract}

Hasil: Rerata kadar cystatin C serum pada preeklampsia berat sebesar 1,169 $\pm 0,311 \mathrm{mg} / \mathrm{l}$. Rerata kadar cystatin C serum pada hamil normal sebesar 0,929 $\pm 0,166$. Terdapat perbedaan yang bermakna rerata kadar cystatin $C$ serum pada preeklampsia berat dibandingkan dengan hamil normal ( $p=0,001)$.

Kesimpulan: Terdapat perbedaan bermakna kadar cystatin $C$ serum pada preekampsia berat dibandingkan dengan hamil normal.

[Maj Obstet Ginekol Indones 2014; 2-1: 22-27]

Kata kunci: cystatin $C$, endoteliosis glomerulus, preeklampsia berat.

Correspondence: Kurnia Meity Isasari, Department of Obstetrics and Gynecology, Faculty of Medicine University of Sriwijaya, Palembang. Telephone 081278130669 Email: kurnia.supron@gmail.com

\section{INTRODUCTION}

Maternal Mortality and Perinatal Mortality in Indonesia is still very high. According to the 2007 SDKI survey data, Indonesia's maternal mortality rate was 228 per 100,000 live births, which is still the highest maternal mortality rate in Asia. ${ }^{1}$ In addition to hemorrhage, the major cause of maternal death in Indonesia at this time is preeclampsia. According to the 2007 report by National Development Body (Bapenas), preeclampsia-eclampsia causes $25 \%$ of maternal deaths in Indonesia and became the second most common cause of maternal mortality after hemorrhage (30\%). ${ }^{1,2}$

Preeclampsia is a syndrome characterized by increased blood pressure accompanied by proteinuria, in pregnant women who previously did not have hypertension. ${ }^{3}$ This syndrome usually appears at the end of the second trimester to the third trimester of pregnancy. Preeclampsia can have serious implication for both mother and fetus. ${ }^{4}$ Minimum criteria of pre-eclampsia is characterized by blood pressure of more than 140/90 mmHg after 20 weeks of gestation accompanied by proteinuria $\geq 300 \mathrm{mg} / 24$ hours.., 6

World Health Organization (WHO) stated that the incidence of preeclampsia is about 0.51 to $38.4 \%$. In Indonesia, the incidence of severe preeclampsia is approximately $3-10 \%{ }^{2}$ At dr. Soetomo Hospital, it is reported that in 1990 the perinatal mortality rate is $7.4 \%$ in preeclampsia and eclampsia, and the rate of preeclamsia and eclampsia was 32.3\%. In Dr. Mohammad Hoesin Hospital Palembang, the average incidence rate between 2005- 
2009 was $9.9 \%$ per year. $^{7}$ This situation is a challenge for health workers considering the target set in 2010 by the Health Department to reduce maternal mortality to be $125 / 100.000$ live births and neonatal mortality to be lower 15/1000 live births.

Etiology of preeclampsia is still unknown. There are several hypotheses to explain the pathogenesis of preeclampsia. Among others is a theory of abnormal placental development, predisposing maternal constitutional factors placental ischemia, immune maladaptation, and genetic susceptibility. ${ }^{8-14}$ What considered as important in the development of preeclampsia theory is incomplete trophoblast invasion or regarded as abnormal cytotrophoblast invasion of the maternal spiral arteries, resulting in inadequate trophoblast perfusion, further spread of the toxin, endothelial cell dysfunction and vascular endothelial function imbalance vasodepressor maternal. ${ }^{14}$

In preeclampsia and eclampsia changes in the anatomy and physiology will occur in various organs such as the hemodynamic system, kidneys, retina and blood chemistry. Various aspects of biochemistry is closely related to preeclampsia. Conditions of good nutrition before pregnancy play an important role in preventing preeclampsia. The latest concept of preeclampsia is focused on vascular endothelial dysfunction as a factor involved in the pathogenesis of preeclampsia. Free radical involvement in preeclampsia may be associated with endothelial dysfunction. Metabolic effects of lipid peroxidation causes an imbalance of prostacyclin and thromboxane production is characterized by impaired blood pressure and coagulation process. ${ }^{11,15}$

In normal pregnancy glomerular hyperfiltration in the kidneys, where there was an increase of 40$60 \%$. Hyperfiltration is caused by the decrease in oncotic pressure in the capillaries glomerulus. Decrease of plasma oncotic pressure in the glomerular capillaries caused by two phenomena: firstly the result of hypervolemia hemodilution would decrease the concentration of protein in the plasma into the glomerular microcirculation. The second because of the increase in renal plasma flow. In addition to the changes that pregnancy will increase kidney size $1 \mathrm{~cm}$. While LFG in preeclampsia decreased from $149 \mathrm{ml} / \mathrm{min}$ to $91 \mathrm{ml} / \mathrm{min}^{16}$

Glomerulus is selective in determining the molecule to be filtered by size and electrical charge. Substances with small molecular weight can be freely through the glomerular membrane so that these substances have similar concentrations in plasma. ${ }^{17}$ Cystatin $\mathrm{C}$ has a small molecular size $(13.3 \mathrm{kDa})$. Levels in serum may reflect glomerular filtration rate (GFR) in non pregnant women. ${ }^{18}$ Ray (2003), cystatin $C$ is the strongest inhibitor of the extracellular cysteine protease that has the effect of setting the else protease. ${ }^{19}$

Increased serum levels of cystatin $\mathrm{C}$ in preeclampsia in later pregnancy and due to changes in the kidney in the regulation of protein. But also due to the synthesis and secretion of proteins that increase. ${ }^{20,21}$ Cystatin $C$ levels in maternal plasma is a good indicator to determine the beginning and the degree of severity of preeclampsia. In a study of the renal biopsy, it was found that the levels of cystatin $\mathrm{C}$ was associated with the degree of change in the structure of the kidney (glomerular endotheliosis) that are characteristic of preeclampsia. Cystatin C levels are also associated with GFR in normal pregnancy and preeclampsia and advanced pregnancy. ${ }^{16,22}$ Cystatin $\mathrm{C}$ is only eliminated through the kidneys, ie after freely filtered by the glomerulus. Cystatin C is not secreted by the tubules but entirely resorption and catabolized by tubular. Therefore levels in plasma can describe LFG. $^{23}$

Changes in renal morphology in preeclampsia are characterized by endotheliosis glomerular filtration barrier will prevent, so in preeclampsia GFR decline. Therefore cystatin $C$ levels in plasma can be used as a marker of renal morphological changes and is used as a sign of a transition to a state of normal pregnancy and severity preeclampsia. ${ }^{20,24}$

This study aimed to compare the serum cystatin $\mathrm{C}$ levels in severe preeclampsia and normal pregnancy.

\section{METHOD}

The study population is pregnant women with $\geq$ 37 weeks gestation. Subjects were pregnant women with gestational age $\geq 37$ weeks diagnosed with severe preeclampsia and normal pregnancy that came and got treatment in the Department of Obstetrics and Gynecology Hospital dr. Moh. Hoesin/Faculty of Medicine Sriwijaya University, from March 2013 to April 2013. The sampling method was consecutive sampling, determined by the order of arrival of patients who met the inclusion criteria. Inclusion criteria were women diagnosed 
with preeclampsia and normal pregnancy, single life fetus, $\geq 37$ weeks gestational age, willing to join the study and signed an informed consent sheet. Exclusion criteria were pregnancy with complications of other diseases such as kidney disease, liver disease antepartum hemorrhage, chronic infectious diseases, diabetes mellitus, and anemia, and pregnant with a dead fetus in the womb. Examination of serum cystatin $C$ levels in automation with particle-enhanced nephelometric immunoassay (PENIA) methods with reagent $\mathrm{N}$ latex cystatin $\mathrm{C}$, OQNM G13 E0541 (109) with the tools in the laboratory Behring Prospec Nephelometer Prodia Palembang.

\section{RESULTS AND DISCUSSION}

Common characteristics of subjects that were encountered in this study suggests that the dis-tribution of the age of majority in the range of subjects $20-35$ years old were 19 subjects $(63.3 \%)$ in severe preeclampsia and 25 subjects $(83.3 \%)$ in normal pregnant with the most parity is multiparous where the severe preeclampsia group, there were 12 subjects $(40.0 \%)$ and 17 normal pregnant subjects $(56.7 \%)$.

Table 1. Subject Characteristic.

\begin{tabular}{lcc}
\hline \hline \multicolumn{1}{c}{ Characteristic } & $\begin{array}{c}\text { Severe } \\
\text { preeclampsia } \\
(\mathbf{n = 3 0 )}\end{array}$ & $\begin{array}{c}\text { Normal } \\
\text { pregnancy } \\
(\mathbf{n}=30)\end{array}$ \\
\hline Age (yr) & $2(6.7)$ & $2(6.7)$ \\
- $<20$ & $19(63.3)$ & $25(83.3)$ \\
- $20-35$ & $9(30.0)$ & $3(10.0)$ \\
- $\geq 35$ & & \\
Parity & $9(30.0)$ & $12(40.0)$ \\
- Primipara & $12(40.0)$ & $17(56.7)$ \\
- Multipara & $9(30.0)$ & $1(3.3)$ \\
- Grandemultipara & & \\
Address & $15(50.0)$ & $23(76.7)$ \\
- Urban area & $15(50.0)$ & $7(23.3)$ \\
- Rural area & & \\
Graduate from school & $5(16.7)$ & $0(0.0)$ \\
- Elementary & $12(40.0)$ & $6(20.0)$ \\
- Junior High & $13(43.3)$ & $22(73.3)$ \\
- Senior High & $0(0.0)$ & $2(6.7)$ \\
- Bachelor degree & & \\
& &
\end{tabular}

Job

\begin{tabular}{lcc} 
- Housewife & $22(73.3)$ & $28(93.4)$ \\
- Labour & $4(13.3)$ & $0(0.0)$ \\
- Farmer & $3(10.0)$ & $0(0.0)$ \\
- Private employee & $0(0.0)$ & $1(3.3)$ \\
- Government employee & $0(0.0)$ & $1(3.3)$ \\
- Trade & $1(3.3)$ & $0(0.0)$ \\
\hline \hline
\end{tabular}

Mean systolic and diastolic blood pressure severe preeclampsia group was higher than the normal pregnant group $166.3 \pm 10.33$ and $105.33 \pm$ $6.81 \mathrm{mmHg}$ versus $116.00 \pm 8.94 \mathrm{mmHg}$ and 75.67 $\pm 5.68 \mathrm{mmHg}$ and there are significant differences in systolic and diastolic blood pressure in both groups $(p=0.000)$. This result is in line with research by Kristensen et al which found significant differences in systolic and diastolic blood pressure between preeclampsia compared with normal pregnancy $(\mathrm{p}<0.001)$ with a mean systolic and diastolic blood pressure at preeclampsia was $151 \pm 14$ and $100 \pm 7 \mathrm{mmHg}$ and the normal pregnant 118 \pm 12 and $70 \pm 9 \mathrm{mmHg}$.

Table 2. Subject Characteristic.

\begin{tabular}{lcc}
\hline \hline \multicolumn{1}{c}{ Characteristic } & $\begin{array}{c}\text { Severe } \\
\text { preeclampsia } \\
\text { (mean }+ \text { SD) }\end{array}$ & $\begin{array}{c}\text { Normal } \\
\text { pregnancy } \\
\text { (mean } \pm \text { SD) }\end{array}$ \\
\hline $\begin{array}{l}\text { Systolic blood } \\
\text { pressure (mmHg) }\end{array}$ & $166.3 \pm 10.33$ & $116.0 \pm 8.94$ \\
$\begin{array}{l}\text { Systolic blood } \\
\text { pressure (mmHg) }\end{array}$ & $105.33 \pm 6.81$ & $75.67 \pm 5.68$ \\
$\begin{array}{l}\text { Level of cystatin } \\
\text { C }(\mathrm{mg} / \mathrm{l})^{* *}\end{array}$ & $1.169 \pm 0.311$ & $0.929 \pm 0.166$ \\
\hline$p=0.000^{*}, p=0.001^{* *}$ & & \\
\hline
\end{tabular}

Test results obtained mean levels of Cystatin C, Cystatin $\mathrm{C}$ levels higher severe preeclampsia group compared with the normal pregnant group is 1.169 $\pm 0.311 \mathrm{mg} / \mathrm{l}$ versus $0.929 \pm 0.166 \mathrm{mg} / \mathrm{l}$ and there is a significant difference $(\mathrm{p}=0.001)$.

In this study also found a significant association between cystatin C levels with Means Arterial Pressure with correlation coefficient of 0.460 . However, this correlation suggests that the relationship between Cystatin $\mathrm{C}$ with moderate MAP. The coefficient of determination (r2) of 0.212 means that Cystatin $\mathrm{C}$ can be said to have an influence only $21.2 \%$ to $78.8 \%$ while the MAP is influenced by other factors (Figure 1). 


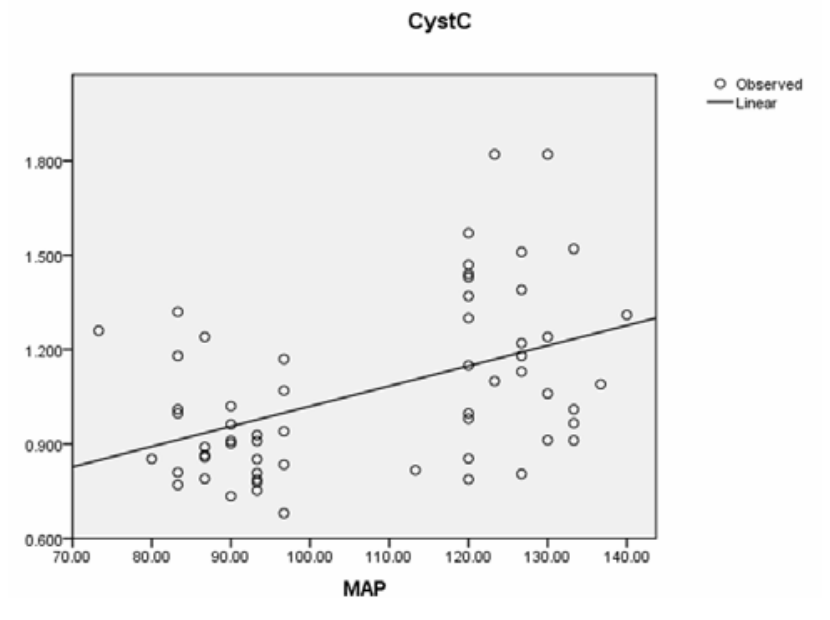

Figure 1. Relationship between Cystatin C and Means Arterial Pressure.

\section{DISCUSSION}

Common characteristics of subjects that were encountered in this study suggests that the distribution of the age of majority in the range of subjects 20 -35 years old were 19 subjects $(63.3 \%)$ in severe preeclampsia and 25 subjects $(83.3 \%)$ in normal pregnant with the most parity is multiparous where the severe preeclampsia group, there were 12 subjects $(40.0 \%)$ and 17 normal pregnant subjects $(56.7 \%)$. Distribution characteristics of this age are not much different from the research done on Kristensen $\mathrm{K}$ et al Cystatin C, B-2 microglobulin and $ß$-trace protein in preeclampsia, the mean age of study subjects obtained was $32 \pm 4$ years. ${ }^{25}$ In Strevens $\mathrm{H}$ et al study of serum cystatin $\mathrm{C}$ to assess GFR in pregnant and non-pregnant women followed by many women with an average age of 29 \pm 5 years. $^{20}$

On the characteristics of parity, it seems that there are many groups of severe preeclampsia in multiparous, this is different to that reported Sibai and Cunningham (2009) from various review studies around the world that the incidence of preeclampsia in primiparous. ${ }^{8}$ The difference is probably due to the research this cross sectional study period between March and April 2013 in which the research subjects who met the inclusion criteria are mostly multiparous.

Mean systolic and diastolic blood pressure severe preeclampsia group was higher than the normal pregnant group $166.3 \pm 10.33$ and $105.33 \pm$ $6.81 \mathrm{mmHg}$ versus $116.00 \pm 8.94 \mathrm{mmHg}$ and 75.67 $\pm 5.68 \mathrm{mmHg}$ and there are significant differences in systolic and diastolic blood pressure in both groups $(p=0.000)$. This result is in line with research by Kristensen et al which found significant differences in systolic and diastolic blood pressure between preeclampsia compared with normal pregnancy $(\mathrm{p}<0.001)$ with a mean systolic and diastolic blood pressure at preeclampsia was $151 \pm 14$ and $100 \pm 7 \mathrm{mmHg}$ and the normal pregnant 118 \pm 12 and $70 \pm 9 \mathrm{mmHg}$.

Test results obtained mean levels of Cystatin C, Cystatin C levels higher severe preeclampsia group compared with the normal pregnant group is 1.169 $\pm 0.311 \mathrm{mg} / \mathrm{l}$ versus $0.929 \pm 0.166 \mathrm{mg} / \mathrm{l}$ and there is a significant difference $(\mathrm{p}=0.001)$. Results of this study are in line with previous research conducted by Strevens $\mathrm{H}$ et al who conducted a study on cystatin $\mathrm{C}$ were followed 36 preeclamptic women and 12 normal pregnant which found significant differences $(p<0.0001) .{ }^{22}$ Similarly, research conducted by Kristensen et $\mathrm{al}^{25,26}$, Yeni $\mathrm{CM}^{27}$, reported significant differences in preeclampsia compared with normal pregnancy.

Based on the statistical analysis we did, found a significant effect of Cystatin $C$ levels with incident severe preeclampsia $(p=0.005)$. Changes in renal morphology in preeclampsia are characterized by endotheliosis glomerular filtration barrier will prevent, so in preeclampsia GFR decline. Substances with small molecular weight, including Cystatin C may be freely through the glomerular membrane. Cystatin $C$ is not secreted by the tubules but entirely resorption and catabolized by the tubules, so that levels in plasma can describe LFG. ${ }^{23}$ Therefore change the filtration barrier is an increase in Cystatin C levels in severe preeclampsia. Strevens et al reported the results of research that was followed by 36 preeclamptic women and 12 normal pregnant kidney biopsy is done to determine the degree of difference endotheliosis. The result is a serum Cystatin C levels had a significant correlation with the degree of endotheliosis and increased glomerular volume in pregnancies with preeclampsia $(\mathrm{p}<0.001) .{ }^{22}$

In this study also found a significant association between Cystatin C levels with Means Arterial Pressure with correlation coefficient of 0.460 . However, this correlation suggests that the relationship between Cystatin C with moderate MAP. The coefficient of determination (r2) of 0.212 means that Cystatin $\mathrm{C}$ can be said to have an influence only $21.2 \%$ to $78.8 \%$ while the MAP is influ- 
enced by other factors (Figure 1). This is consistent with the pathogenesis of preeclampsia is very complex with many factors that are believed to contribute to disease progression such as abnormal development of the placenta, maternal predisposing factors, oxidative stress, immune maladaptation and genetic factors. Each of these factors play a role in maternal systemic endothelial dysfunction that causes vasoconstriction and decreased tissue and organ perfusion. ${ }^{28}$

Yanik $\mathrm{F}$ et al reported an increase in preeclampsia higher lipid peroxidation, as well as dealing with increasing bloodpressure. ${ }^{29}$ In preeclampsia endothelial damage causing leakage especially in the micro vascular system. Under normal circumstances, endothelial cells produce prostacyclin relatively high. While platelets produce thromboxane. If there is damage to the endothelial prostacyclin production will decrease. Instead thromboxane increases because of the many platelet aggregation. Consequently prostacyclin-thromboxane ratio decreased the vasoconstriction, thus the effect will be greater and causing hypertension. ${ }^{10}$

\section{CONCLUSIONS}

There was a significant differences between maternal serum levels of Cystatin $C$ in severe preeclampsia compared with normal pregnancy.

\section{REFERENCES}

1. Banjarmasin Post. Angka kematian ibu di Indonesia. Banjarmasin Post.com 2012 [Diunduh 5 Februari 2012]:[1 screen]. Diambil dari: http://Banjarmasin Post.com

2. Sofoewan MS. Waspadai eklampsia dan preeklampsia, Kompas Cetak [serial online] Oktober 2008 [Diunduh 5 Februari 2012]:[1 screen]. Diambil dari: http://www.cetak kompas.com.

3. Cunningham FG, Mac Donald PC, Gant NF, Leveno KJ, Gilsrap LC, Hankins GD, et al. Williams Obstetrics $21^{\text {th }}$ ed. London: Prentice-Hall International; 2001: 567-618.

4. Davey DA, MacGillivray I. The classification and definition of the hypertensive disorders of pregnancy. Am J Obstet Gynecol. 1988; 158: 892-8.

5. Rudra P, Basak S, Patil D, Latoo M. Recent advance in management of preeclampsia. BMC, 2011; 4: 3.

6. Kelompok kerja penyusunan "Pedoman pengelolaan hipertensi dalam kehamilan di Indonesia" Himpunan Kedokteran Fetomaternal POGI. Jakarta; 2005.

7. Rosalina. Faktor-faktor resiko kematian maternal dengan preeklampsia dan eklampsia di RSMH Palembang. Tesis PPDS yang tidak dipublikasikan. Bagian Obstetri dan Ginekologi RSMH Palembang; 2012.

8. Cunningham FG, Leveno KJ, Bloom SL, Hauth JC, Gilstrap III L, Wenstrom KD. Hypertensive disorders in pregnancy. In:
Williams Obstetrics. 23rd ed. New York: McGraw-Hill; 2010: 705-56.

9. Churchill D, Beevers DG. Clinical assesment and investigation of the hypertensive disorders of pregnancy. In: Hypertension in pregnancy. $1^{\text {st }}$ ed. London: BMJ Books. 1999: 45-6.

10. Angsar MD. Hipertensi dalam kehamilan. Dalam: Wiknjosastro H, Saifuddin AB, Rachimhadhi T. Ilmu Kebidanan. Edisi keempat. Jakarta: Yayasan Bina Pustaka Sarwono Prawirohardjo. 2008: 530-61.

11. Chamber JC, Fusi L, Malik SI, Hasrkard OD, Swiet DM, Kooner SJ. Association of maternal endothelial dysfunction with preeclampsia. JAMA. 2001; 285: 1607-12.

12. Lyall F, Belfort M. Preeclampsia. Etiology and clinical practice. Cambridge University Press. 2007.

13. Redman CW, Sargent IL. Latest advances in understanding preeclampsia. Science. 2005; 308: 1592-4.

14. Robert JM, Hubel CA. Recent insight into the pathogenesis of pre-eclampsia. Placenta. 2002; 23: 359-72.

15. K Patricia, Agatisa, Ness BR, Roberts MJ, Costantino PJ, Kuller HL, et al. Impairment of endothelial function in women with a history of preeclampsia an indicator of cardiovascular risk. Am J Physiol Heart Clin. 2004; 286: 1389-93

16. Curhan G. Cystatin C a marker of renal function or something more? J Clin Chemist. 2005; 51: 293-4.

17. Guyton end Hall. Urine formation by the kidneys: Glomerular filtration, renal blood flow, and their control. In: Textbook of Medical Physiology. Ninth ed. W.B. Saunders. 1996: 315-48.

18. Grubb AO. Cystatin C properties and use as diagnostic marker. Adv Clin Chem. 2000; 35: 63-99.

19. Ray S, Lukyanov P, Ochieng J. Members of the cystatin superfamily interact with MMP-9 and protect it from autolytic degradation without affecting its gelatinotic ac-tivities. Biochim Biophys Acta. 2003; 1652: 91-102.

20. Strevens H, Wide-Swensson D, Torffvit O. Serum cystatin C for assesment of glomerular filtration rate in pregnant and non-pregnant women. Indications of altered filtration process in pregnancy. Scand J Clin Lab Invest. 2002; 62: 241-48.

21. Akbari A, Lepage N, Keely E, Clark HD, Jaffey J, MacKinnon $\mathrm{M}$ et al. Glomerular endotheliosis in normal pregnancy and preeclampsia. BJOG: an Inter J Obstet Gynecol. 2005; 112: 575-8.

22. Strevens H, Wide-Swensson D, Grubb A. Serum cystatin C reflect glomerular endotheliosis in normal, hypertensive and preeclamptic pregnancies. BJOG. 2003; 110(9): 825-30.

23. Fliser 0, Ritz E. 2001. Serum cystatin C Concentration as marker of renal dysfunction in the elderly. Am J Kidney Diseases, 2001; 37(1): 78-83.

24. Strevens H, Wide-Swensson D, Grubb A. Serum cystatin C is a better marker for preeclampsia than serum creatinine or serum urate. Scand J Clin Lab Invest. 2001; 61: 575-80.

25. Kristensen K, Wide-Swensson D, Schmidt C, Blirup-Jensen S, Lindstrom V, Strevens H. Cystatin C, B-2-microglobulin and $ß$-trace protein in preeclampsia. Acta Obstet Gynecol. 2007; 86: 921-6.

26. Kristensen K, Lindstrom V, Schmidt C, Blirup-Jensen S, Grubb A, Wide-Swensson D et al. Temporal changes of the plasma levels of cystatin C, ß-trace protein, ß2-microglobulin, urate and creatinine during pregnancy indicate continuous alteration in the renal filtration process. Scan J Clin Lab Invest. 2007; 67: 612-8. 
27. Yeni CM. Perbandingan kadar cystatin $\mathrm{C}$ dan gambaran arus darah arteri renalis pada kehamilan normal dan kehamilan preeklampsia. Departemen Obstetri dan Ginekologi Fakultas Kedokteran Universitas Indonesia RSUPN dr. Cipto Mangunkusumo Divisi Fetomaternal. Jakarta. 2010.
28. Weissgerber TL, Wolfe LA, Davies GAL. The role of regular physical activity in preeclampsia prevention. Med Sci. Sports Exerc. 2004; 12(36): 2024-31.

29. Yanik FF, Arnanvernes R, Yanik A, Celik C. Preeclampsia associated with increased lipid peroxidation and decreased serum vitamin E level. Int J Gynecol Obstet. 1999; 64: 27-33. 